\title{
PEMANFAATAN LAPORAN KEUANGAN KAS MASJID BERBASIS WEB
}

\author{
Andri Nata ${ }^{1}$, Nasrun Marpaung ${ }^{2}$, Rolly Yesputra ${ }^{3}$, Afdhal Syafnur ${ }^{4}$ \\ ${ }^{1}$ Manajemen Informatika, STMIK Royal Kisaran \\ ${ }^{1,3}$ Sistem Informasi, STMIK Royal Kisaran \\ ${ }^{4}$ Sistem Komputer, STMIK Royal Kisaran \\ e-mail: andrinata0202@gmail.com
}

\begin{abstract}
Abstrak
Kemajuan teknologi komputer sebagai pendukung pemrosesan data dan informasi telah menjadi kebutuhan pokok dalam bidang apapun. Pemanfaatan Sistem Informasi sebagai bentuk transparansi kegiatan masjid Ar-Ramadhan dalam peningkatan kualitas kinerja BKM dalam era modern tentunya membutuhkan media informasi seperti website untuk menyediakan informasi yang uptodate sebagai bentuk kepedulian dan bentuk kinerja yang baik yang dapat diakses oleh masyarakat sekitar Dusun 2 Kede Nangka Desa Urung pane. Badan Kemakmuran Masjid (BKM) dalam pengelolaan keuangan harus bersifat transparansi agar para jamaah memiliki kepercayaan dan nyaman dalam berinfaq dan menyalurkan sumbangannya ke masjid tersebut. Untuk itu diperlukan pengelolaan laporan keuangan berbasis web dimana dalam pemanfaatannya bisa menampilkan data yang akurat dan mudah dimudahkan. Fitur yang digunakan dalam aplikasi ini dapat menampilkan laporan per-hari, per-bulan dan per-tahun sesuai kategori yang diinginkan. Sehingga dibutuhkan sebuah aplikasi yang dapat memberikan solusi terhadap permasalahan yang ada. Aplikasi ini dibuat menggunakan bahasa pemrograman PHP yang menghasilkan aplikasi yang dapat diakses dari manapun dan kapanpun sehingga memudahkan pengguna. Aplikasi pemanfaatan laporan keuangan berbabasi web juga merupakan aplikasi yang dapat mengelola informasi kas masjid yang memudahkan masyarakat dusun 2 Kede Nangka Desa Urung pane dalam mengelola transaksi keuangan kas masjid.
\end{abstract}

Kata kunci: Website, Aplikasi Keuangan, Masjid

\begin{abstract}
Advances in computer technology as a supporter of data and information processing have become a basic need in any field. Utilization of Information Systems as a form of transparency of the activities of the Ar-Ramadhan mosque in improving the quality of BKM performance in the modern era of course requires information media such as websites to provide up-to-date information as a form of concern and a form of good performance that can be accessed by the community around Dusun 2 Kede Nangka, Urung Pane Village. The Mosque Prosperity Agency (BKM) in financial management must be transparent so that worshipers have confidence and are comfortable in donating and channeling their donations to the mosque. For this reason, it is necessary to manage web-based financial reports where in its use it can display accurate and easy data. The features used in this application can display reports per day, per month and per year according to the desired category. So we need an application that can provide solutions to existing problems. This application is made using the PHP programming language which produces applications that can be accessed from anywhere and anytime, making it easier for users. The application for utilizing web-based financial reports is also an application that can manage mosque cash information that makes it easier for the community of Dusun 2 Kede Nangka, Urung Pane Village to manage mosque cash financial transactions.
\end{abstract}

Keywords: Website, Financial Application, Mosque

\section{PENDAHULUAN}

Pengabdian masyarakat adalah suatu kegiatan yang bertujuan membantu masyarakat tertentu dalam beberapa aktivitas tanpa mengharapkan imbalan dalam bentuk apapun. Secara umum program ini dirancang oleh berbagai universitas atau institut yang ada di Indonesia untuk memberikan kontribusi nyata bagi bangsa Indonesia, khususnya dalam mengembangkan 
kesejahteraan dan kemajuan bangsa Indonesia. Kegiatan Pengabdian Masyarakat merupakan salah satu bagian dari Tri Dharma Perguruan Tinggi.

Perkembangan teknologi informasi dan komunikasi sangat berkembang dengan pesat yang mempengaruhi gaya pikir dan kemampuan manusia. Setiap pekerjaan tentunya ingin diselesaikan dengan cepat dan tepat serta dengan hasil yang baik. Kemajuan teknologi komputer sebagai pendukung pemrosesan data dan informasi telah menjadi kebutuhan pokok dalam suatu instansi. Instansi jasa pelayanan yang memberikan pelayanan kepada masyarakat, sangat membutuhkan kecepatan pelayanan informasi sehingga dapat memberikan pelayanan yang optimal kepada penggunanya.

Pemanfaatan Sistem Informasi sebagai bentuk transparansi keuangan masjid Ar-Ramadhan dalam peningkatan kualitas BKM dalam era modern tentunya membutuhkan media informasi seperti website untuk menyediakan informasi yang up to date sebagai bentuk kepedulian dan bentuk kinerja yang baik yang dapat diakses oleh masyarakat sekitar Dusun II Desa Urung Pane Kec. Setia Janji. Aplikasi sistem keuangan yang dibuat akan menjadi media atau sistem informasi yang menyampaikan seluruh jenis kegiatan keuangan di lingkungan Masjid Ar-Ramadhan.

Website adalah sekumpulan halaman web yang saling berhubungan yang umumnya berada pada peladen yang sama berisikan kumpulan informasi yang disediakan secara perorangan, kelompok, atau organisasi. Sebuah situs web biasanya ditempatkan setidaknya pada sebuah server web yang dapat diakses melalui jaringan seperti internet, ataupun jaringan area lokal (LAN) melalui alamat internet yang dikenali sebagai url. Gabungan atas semua situs yang dapat diakses publik di internet disebut pula sebagai World Wide Web atau lebih dikenal dengan singkatan WWW. Sebuah halaman web merupakan berkas yang ditulis sebagai berkas teks biasa (plain text) yang diatur dan dikombinasikan sedemikian rupa dengan instruksi-instruksi berbasis HTML, kadang-kadang pula disisipi dengan sekelumit bahasa skrip. Berkas tersebut kemudian diterjemahkan oleh peramban web dan ditampilkan seperti layaknya sebuah halaman pada monitor komputer.

Oleh sebab itu, pemanfaatan teknologi informasi dalam bidang pembuatan aplikasi keuangan sebagai media informasi akan sangat membantu Masjid Ar-Ramadhan untuk menciptakan kedekatan terhadap masyarakat.

\section{METODE}

Kegiatan pengabdian kepada masyarakat ini dilakukan oleh tim Dosen STMIK Royal Kisaran. Tim pengabdian terdiri dari 4 orang. Tugas masing-masingnya yaitu 1 orang menjadi moderator dan 3 orang lainnya sebagai pemateri atau narasumber.

Metode pelaksaan dalam pengabdian masyarakat ini yaitu presentasi penyampaian materi dan praktikkum langsung. Penguraian materi dimulai dari pengenalan internet, website, blog dan penggunaannya. Pada Pengabdian kepada Masyarakat ini yang menjadi peserta adalah Ketua BKM Ar-Ramadhan, nazir masjid dan pengurus lainnya serta narasumber dari tim pengabdian Dosen STMIK Royal Kisaran.

\section{HASIL DAN PEMBAHASAN}

Pelaksanaan kegiatan pengabdian ini berjalan sesuai dengan rencana yang telah ditetapkan. Hal ini disebabkan oleh adanya kerjasama yang baik antara tim pelaksana pengabdian dengan pengurus BKM Ar-Ramadhan. Pada saat pelaksanaan, seluruh pengurus yang mengikuti kegiatan pelatihan tersebut dengan semangat dan antusiasme yang tinggi. Hal ini terbukti dengan adanya perhatian dan ketekunan para peserta dalam menjalankan semua instruksi yang diberikan oleh tim pelaksana. Pada waktu pelatihan berlangsung, peserta juga terlihat aktif dalam menanyakan segala hal yang belum mereka ketahui.

Para narasumber mendampingi peserta dengan penuh tanggungjawab dan kesabaran untuk memastikan bahwa seluruh peserta pelatihan dapat menguasai materi dengan baik. Narasumber juga memanfaatkan peserta yang sudah memiliki pengetahuan lebih banyak dari peserta lainnya untuk dapat memberikan bimbingan. Hal tersebut dapat membuat suasana pelatihan menjadi lebih akrab diantara narasumber dan pengurus BKM. Oleh sebab itu, suasana ini memberikan capaian yang lebih positif demi tercapainya tujuan pelatihan. 
Adapun hasil yang dicapai dalam pelatihan ini adalah peserta pelatihan yang merupakan pengurus BKM dapat mengelola data, manajemen admin pada website untuk postingan berita atau informasi yang baik dengan cepat dan tepat. Sehingga informasi yang disampaikan juga dapat sebagai media mempererat antara masyarakat dusun II Masjid A-Ramadhan dalam hal pelayanan.

Materi dalam pelatihan ini dibuat sesuai dengan kebutuhan dalam menyampaikan informasi kegiatan keagamaan dan transparansi kegiatan melalui media informasi website.

\subsection{Implementasi Aplikasi}

Untuk menggunakan aplikasi tersebut silahkan kunjungi lama http://kas.masjidarramadhan.my.id/login seperti dibawah ini :

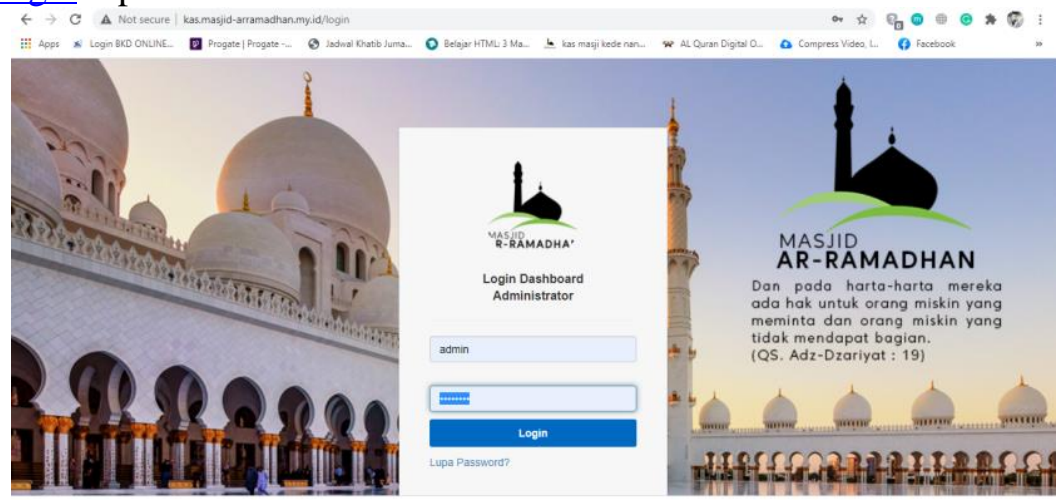

Gambar 1. Tampilan awal admin

Kemudian masukkan username dan password yang sudah diberikan. Apabila sudah login maka akan tampil seperti tampilan dibawah ini :

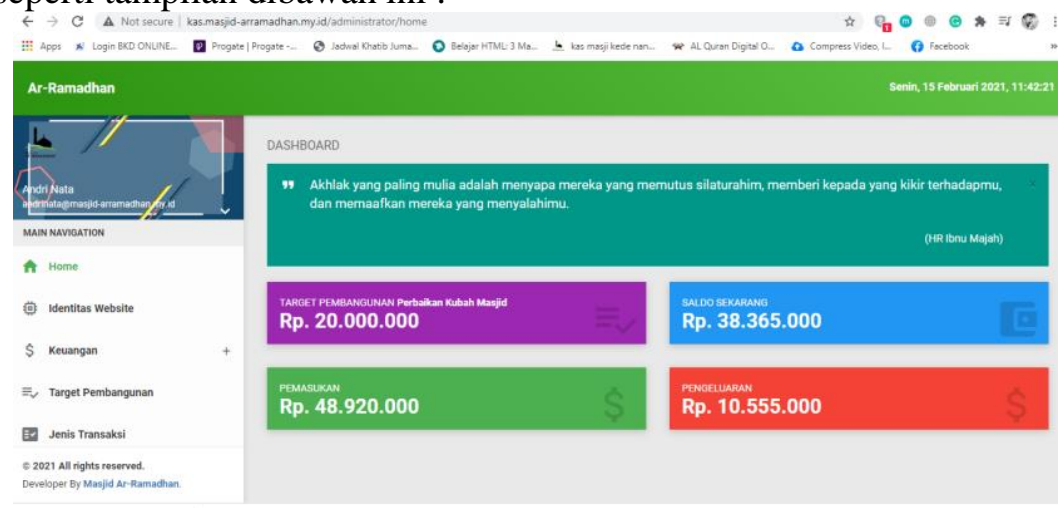

Gambar 2. Tampilan dasboard.

Pada tampilan diatas adalah tampilan menu admin pada aplikasi keuangan. Adapun pada aplikasi tersebut ada beberapa menu yang harus diketahui pengunaan beserta fungsinya yang terdiri dari Home, Identitas website, Keuangan, target Pembangunan, Jenis transaksi. Selanjutnya kita akan membahas pada input keuangan di aplikasi ini. Caranya klik pada menu keuangan >> kelola keuangan seperti gambar dibawah ini :

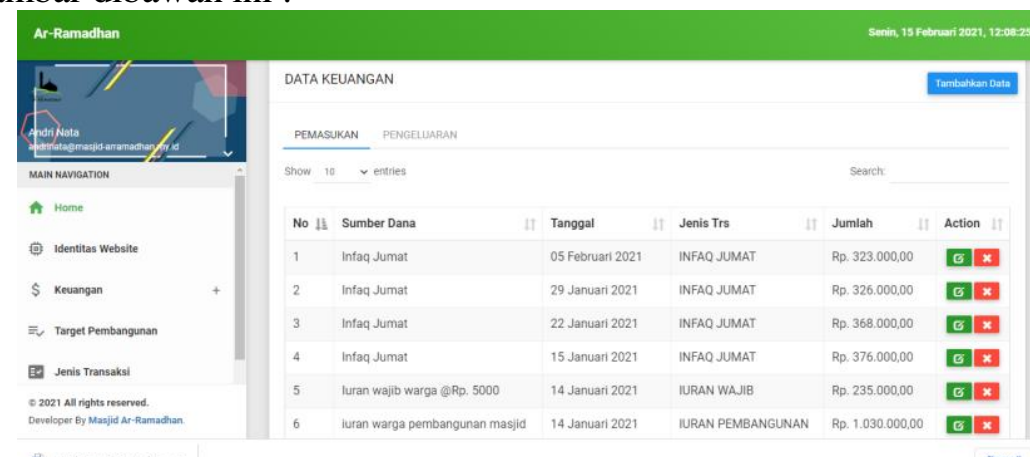

Gambar 3. Data Pemasukan 


\section{SIMPULAN}

Berdasarkan dari pelaksanaan kegiatan Pengabdian Kepada Masyarakat yang telah dilakukan ini, dapat ditarik kesimpulan sebagai berikut: Telah di lakukan pelatihan penggunaan aplikasi kas masjid sebagai sarana informasi keuangan Masjid Ar-Ramadhan oleh BKM ArRamadhan. Pelatihan ini sangat bermanfaat bagi pengurus BKM Ar-Ramadhan dikarenakan sebagai solusi untuk transparansi keadaan keuangan masjid Ar-Ramadhan.

\section{SARAN}

Dalam rangka meningkatkan kualitas dan kuantitas pelaksanaan acara sejenis kiranya dapat memperhatikan saran berikut: Perlunya diberikan pelatihan terhadap sumber daya manusia (SDM) untuk dapat mengembangkan dirinya kearah yang lebih baik. Diharapkan pengembangan lebih lanjut pada pelatihan penggunaan kas berbasis android

\section{UCAPAN TERIMA KASIH}

Kami ucapakan Terima kasih kepada Ketua BKM Ar-Rahmadhan yang telah memberikan kesempatan kepada kami untuk melaksanakan Tri Dharma Perguruan Tinggi.

\section{DAFTAR PUSTAKA}

S. Supriyono and E. Muslimah, "Perancangan Sistem Informasi Manajemen Kas Berbasis Web Studi Kasus: RS dr. Etty Asharto Batu," Matics, vol. 10, no. 1, p. 21, 2018, doi: 10.18860/mat.v10i1.4302.

A. I. N. Muhammad Agung Setiabudi, "Aplikasi Sistem Informasi Penjualan Motor Custom Berbasis Website Menggunakan Framework Codeigniter," J. Manag. Inf., vol. 9, p. 2, 2019.

Y. Nurhayati, "Aplikasi Akuntansi Penatausahaan Keuangan Desa Menggunakan Framework Codeigniter," Buff 